Provided for non-commercial research and education use. Not for reproduction, distribution or commercial use.

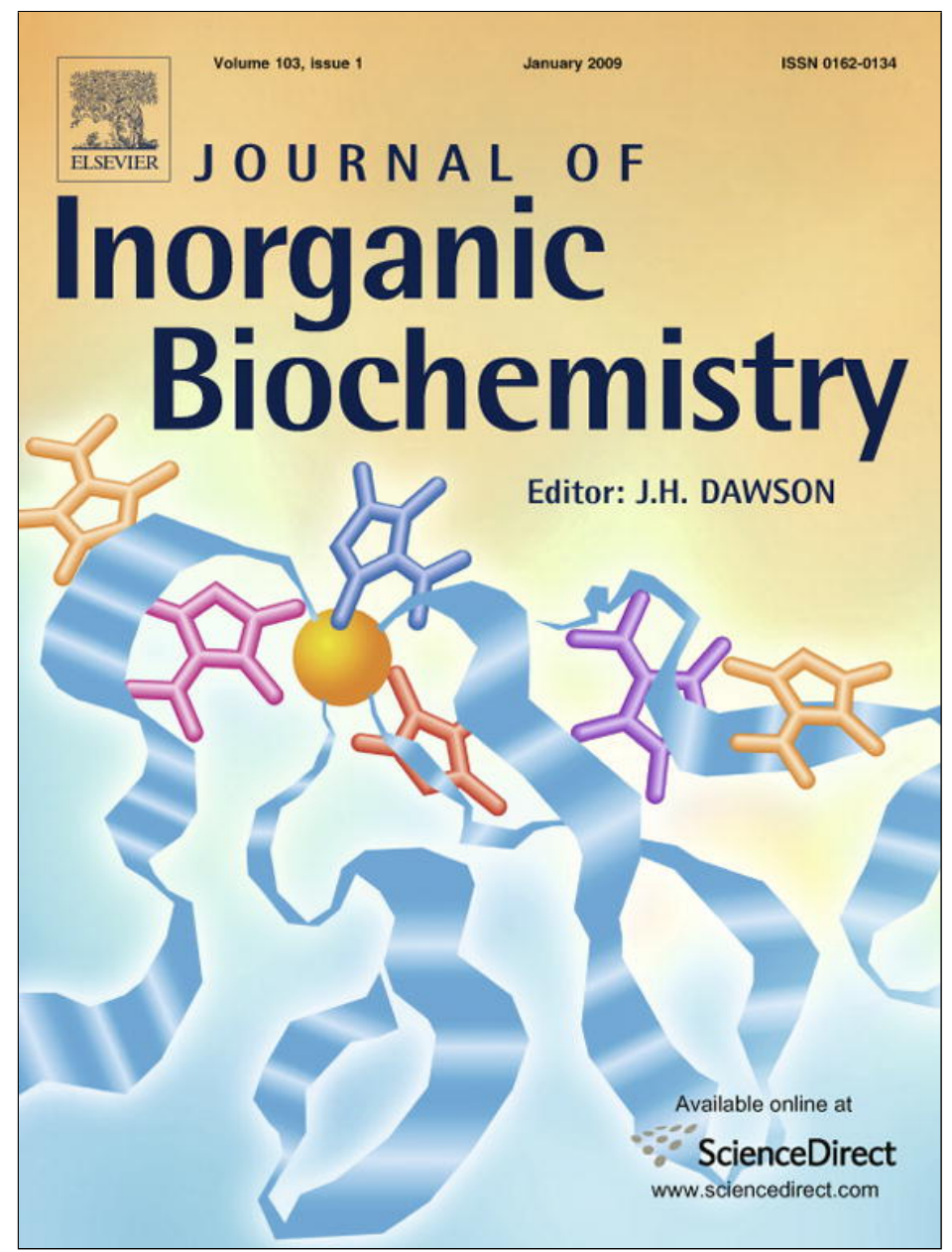

This article appeared in a journal published by Elsevier. The attached copy is furnished to the author for internal non-commercial research and education use, including for instruction at the authors institution and sharing with colleagues.

Other uses, including reproduction and distribution, or selling or licensing copies, or posting to personal, institutional or third party websites are prohibited.

In most cases authors are permitted to post their version of the article (e.g. in Word or Tex form) to their personal website or institutional repository. Authors requiring further information regarding Elsevier's archiving and manuscript policies are encouraged to visit:

http://www.elsevier.com/copyright 


\title{
The interaction of native calf thymus DNA with $\mathrm{Fe}^{\mathrm{III}}$-dipyrido[3,2-a:2',3'-c]phenazine
}

\author{
Alessio Terenzi ${ }^{\mathrm{a}}$, Giampaolo Barone ${ }^{\mathrm{a}, *}$, Arturo Silvestri $^{\mathrm{a}, *}$, Anna Maria Giuliani ${ }^{\mathrm{a}}$, Angela Ruggirello ${ }^{\mathrm{b}}$, \\ Vincenzo Turco Liveri ${ }^{\mathrm{b}}$
}

a Dipartimento di Chimica Inorganica e Analitica “S. Cannizzaro”, Università di Palermo, Viale delle Scienze, Parco d'Orleans II, Edificio 17, 90128 Palermo, Italy

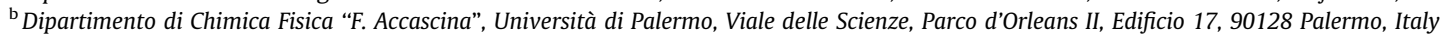

\section{A R T I C L E I N F O}

\section{Article history:}

Received 28 May 2008

Received in revised form 26 August 2008

Accepted 26 August 2008

Available online 5 September 2008

\section{Keywords:}

DNA

dppz

Intercalation

Iron

Spectroscopy

\begin{abstract}
A B S T R A C T
The mono and bis dipyrido[3,2-a:2',3'-c]phenazine (dppz) adducts of iron(III) chloride, i.e. [ $\mathrm{Fe}(\mathrm{dppz})] \mathrm{Cl}_{3}$ and $\left[\mathrm{Fe}(\mathrm{dppz})_{2}\right] \mathrm{Cl}_{3}$, have been synthesized and characterized. The interaction of the $\mathrm{Fe}^{\mathrm{III}} \mathrm{dppz}$ hydrolyzed aquo complex with native calf thymus DNA has been monitored as a function of the metal complex-DNA molar ratio, by variable temperature UV absorption spectrophotometry, circular dichroism (CD) and fluorescence spectroscopy. The results obtained in solution at various ionic strength values give support for a tight intercalative binding of the Fe ${ }^{\mathrm{III}} \mathrm{dppz}$ cation with DNA. In particular, the appearance of induced CD bands, caused by the addition of $\mathrm{Fe}^{\mathrm{III}} \mathrm{dppz}$, indicate the existence of a rigid metal complex-DNA-binding leading to dominating chiral organization of $\mathrm{Fe}^{\mathrm{III}} \mathrm{dppz}$ species within the DNA double helix. The trend of selected $\mathrm{CD}$ bands with the molar concentration of $\mathrm{Fe}^{\mathrm{III}} \mathrm{dppz}$ emphasizes that the presence of high amounts of metal complex induces also the formation of DNA-Fe ${ }^{\text {III }} \mathrm{dppz}$ supramolecular aggregates in solution. The analysis of fluorescence measurements allowed us to calculate a value of the intercalative binding constant comparable to that obtained by UV spectrophotometric titration. Finally, the temperature dependence of the absorbance at $258 \mathrm{~nm}$ shows that the metal complex strongly increases the DNA melting temperature already at metal complex-DNA molar ratio equal to 0.25 suggesting that metal complex intercalation effectively hinders DNA denaturation. Overall, the results of the present study point out that the $\mathrm{Fe}^{\mathrm{III}} \mathrm{dppz}$ aquo complex has DNA-binding properties analogous to those previously reported for the tris-chelate $\mathrm{Fe}^{\mathrm{II}}$ (phen) ${ }_{2} \mathrm{dppz}$ complex (phen = 1,10-phenantroline).
\end{abstract}

(c) 2008 Elsevier Inc. All rights reserved.

\section{Introduction}

In the last decades the synthesis of transition metal complexes that interact with DNA has attracted wide interest for their potential applications as diagnostic probes, anticancer or therapeutics agents and in genomic research [1-3]. Transition metal complexes present different advantages as DNA-binding agents. The metal center offers in fact the possibility of a facile interchange of ligands as well as unique photophysical and electrochemical properties [2]. In this context, particular attention has been devoted to the interaction of DNA with chiral octahedral $\mathrm{M}$ (diimine) ${ }_{3}^{n+}$ type complexes [4], in particular with the heteroleptic $\left[\mathrm{M}(\mathrm{phen})_{2} \mathrm{dppz}\right]^{2+/ 3+}$ complexes $\left(\mathrm{M}=\mathrm{Ru}^{2+}, \mathrm{Co}^{3+}, \mathrm{Cr}^{3+}, \mathrm{Fe}^{2+}, \mathrm{Os}^{2+}, \mathrm{Ni}^{2+}\right.$, phen $=1,10-$ phenantroline, $\mathrm{dppz}=$ dipyrido[3,2-a:2',3'-c]phenazine) [3,5-8]. Barton and coworkers have shown that the dppz ligand (Scheme 1) in such tris-chelates of metal ions displays significant DNA interca-

\footnotetext{
* Corresponding authors. Tel.: +39 091 6575194; fax: +39 091427584 (G. Barone).

E-mail addresses: gbarone@unipa.it (G. Barone), asilves@unipa.it (A. Silvestri).
}

lating ability, preferentially at the major groove side, because of its extended aromatic moiety, while the phenanthroline ligands prefer to bind at the minor groove of DNA [2].

Indeed, all the metal-dppz complexes investigated, independently of the nature of the ancillary ligands, are strong DNA-intercalators. The latter property has been in fact observed, for example, in $\left[\mathrm{Au}(\mathrm{dppz})_{2}\right] \mathrm{Cl}_{3}$ [9], $\left[\mathrm{Cu}(\mathrm{dppz})\left(\mathrm{NO}_{3}\right)\right]\left(\mathrm{NO}_{3}\right)$ [10], $\left[\mathrm{Cu}(\mathrm{dppz})_{2^{-}}\right.$ $\left.\left(\mathrm{NO}_{3}\right)\right]\left(\mathrm{NO}_{3}\right)$ [10], $\left[\mathrm{Ru}\left(\mathrm{NH}_{3}\right)_{4} \mathrm{dppz}\right]^{2+}[11],\left[\mathrm{Ru}(\mathrm{L})_{4} \mathrm{dppz}\right]^{2+}(\mathrm{L}=$ imidazole (Im) or 1-methylimidazole (MeIm)) [12 ], [Cr(dppz $\left.)_{2} \mathrm{Cl}_{2}\right]^{+}[13]$. Nevertheless, due to the limited number of investigations and with the possible sole exception of ruthenium-dppz complexes, detailed information is lacking on the influence of non-chelating ancillary ligands on the stability and optical properties of dppz transition metal complexes and on their DNA-binding modes.

Ruthenium complexes of various ligands have attracted great interest as alternative drugs to cisplatin in cancer chemotherapy, in search of more effective and less toxic metal-based antitumor agents. These complexes have in fact shown similar ligand exchange kinetics to those of platinum(II) antitumor complexes while displaying lower toxicity. However, octahedral $\mathrm{Ru}$ (diimine) ${ }_{3}^{2+/ 3+}$ DNA-intercalators experienced considerable drug 


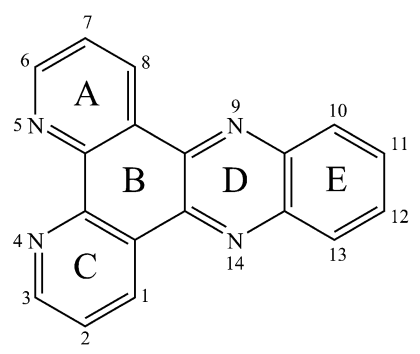

Scheme 1. Structure of dipyrido[3,2-a:2',3'-c]phenazine (dppz).

resistance and, as a consequence, could be used essentially as diagnostic agents for cancer [14].

Concerning the properties of mono-dppz ruthenium complexes with non-chelating ancillary ligands, it has been reported that both complexes [ $\left.\mathrm{Ru}\left(\mathrm{NH}_{3}\right)_{4} \mathrm{dppz}\right]$ [11] and $\left[\mathrm{Ru}(\mathrm{CN})_{4} \mathrm{dppz}\right]$ [15] show different DNA-binding mode or optical properties compared to the related complex $\left[\mathrm{Ru}(\mathrm{bpy})_{2} \mathrm{dppz}\right]$ and to the widely studied $\left[\mathrm{Ru}(\mathrm{phen})_{2} \mathrm{dppz}\right]$. On the other hand, (ImH)[trans- $\mathrm{RuCl}_{4}$ (DMSO$\mathrm{S})(\mathrm{Im})]$ (known as Ru-NAMI-A) has successfully completed Phase I clinical trials as anticancer agent [16] and, interestingly, it has been recently inferred that its hydrolysis is a crucial step for the mechanism of its anticancer activity [17]. Finally, ruthenium complexes have been extensively studied also because of their ability of mimicking the binding of iron to molecules of biological significance, to exploit in such a way the mechanisms that the body has evolved for the transport of iron [18].

Although the interaction of DNA with the intercalator $\mathrm{Fe}^{\mathrm{II}}$ (phen) ${ }_{2} \mathrm{dppz}$ has been recently reported $[7,8]$, to our knowledge no other iron-dppz complexes have been up to now studied. These considerations prompted us to focus our attention on the study of the stability of mono and bis $\mathrm{Fe}^{3+}-\mathrm{dppz}$ complexes in water solution, being well known that $\mathrm{Fe}^{3+}$ is more stable than $\mathrm{Fe}^{2+}$, as well as on their interaction with native calf thymus DNA and on the role of hydrolysis of iron compounds in biological environments.

\section{Experimental}

\subsection{Materials and methods}

Elemental analysis $(\mathrm{C}, \mathrm{H}, \mathrm{N})$ was performed by Vario EL III Elementar gmbh Hanau Germania instrument, $\mathrm{Cl}$ was determined by argentimetric titration, with standard silver nitrate after sample combustion under pure oxygen atmosphere, following the procedure by Schöniger [19]. Fe was determined by flame atomic absorption spectroscopy, using a Perkin-Elmer 372 instrument. The Mössbauer spectrometer and the data reduction method have been described earlier $[20,21]$. The isomer shift was reported with respect to the centroid of a $\alpha$-Fe absorber spectrum at room temperature. Conductivity and $\mathrm{pH}$ measurements were performed by a Crison 522 conductimeter and a Crison GLP 22 pH-meter, respectively, the latter equipped with a Crison 5203 combined electrode.

1,10-Phenantroline-5,6-quinone, o-phenylendiamine, $\mathrm{FeCl}_{3}$, absolute ethanol, calf thymus DNA and tris-hydroxymethyl-aminomethane (Tris- $\mathrm{HCl}$ ) were purchased from Sigma. Bidistilled water was used for preparing buffer solutions. The dppz ligand was synthesized and characterized by closely following previously reported methods [22].

\subsection{Synthesis of $\mathrm{Fe}(\mathrm{dppz}) \mathrm{Cl}_{3}$}

A solution of $\mathrm{FeCl}_{3}(53.8 \mathrm{mg} ; 0.33 \mathrm{mmol})$ in absolute ethanol $(10 \mathrm{~mL})$ was added under stirring to a solution of dppz $(84.7 \mathrm{mg}$;
$0.30 \mathrm{mmol})$ in absolute ethanol $(20 \mathrm{~mL})$. The formation of a deep red precipitate was immediate and the mixture stirred at room temperature for about $1 \mathrm{~h}$. The supernatant was filtered off and the solid washed with ethanol and dried under vacuum. Yield $78 \mathrm{mg}$ (58\%). The compound was characterized by elemental analysis, UV spectroscopy and Mössbauer spectroscopy. (a) $\left(\mathrm{FeCl}_{3} \mathrm{C}_{18} \mathrm{H}_{10} \mathrm{~N}_{4}\right)$, Calcd: $\mathrm{C}$ 48.64; $\mathrm{N} 12.60 ; \mathrm{H} 2.27 ; \mathrm{Cl} 23.93 ; \mathrm{Fe}$ 12.56; found: $\mathrm{C} 48.52 ; \mathrm{N} 12.53 ; \mathrm{H} 2.33 ; \mathrm{Cl} 23.63 ; \mathrm{Fe} 12.25$. (b) ${ }^{57} \mathrm{Fe}$ Mössbauer $\left(77 \mathrm{~K}\right.$, relative to $\alpha$-iron): $\mathrm{IS}=0.38 \mathrm{~mm} \mathrm{~s}^{-1}$, $\mathrm{QS}=0.30 \mathrm{~mm} \mathrm{~s}^{-1}, \Gamma=0.54 \mathrm{~mm} \mathrm{~s}^{-1}$.

\subsection{Synthesis of $\mathrm{Fe}(\mathrm{dppz})_{2} \mathrm{Cl}_{3}$}

A solution of $\mathrm{FeCl}_{3}(27.4 \mathrm{mg} ; 0.17 \mathrm{mmol})$ in absolute ethanol $(10 \mathrm{~mL})$ was added under stirring to a solution of dppz $(84.0 \mathrm{mg}$; $0.30 \mathrm{mmol})$ in absolute ethanol $(20 \mathrm{~mL})$. The formation of a dark red precipitate was immediate and the mixture stirred at room temperature for about $1 \mathrm{~h}$. The supernatant was filtered off and the solid washed with ethanol and dried under vacuum. Yield $79 \mathrm{mg}$ (73\%). The compound was characterized by elemental analysis, UV spectroscopy and Mössbauer spectroscopy. (a) $\left(\mathrm{FeCl}_{3}\right.$ -

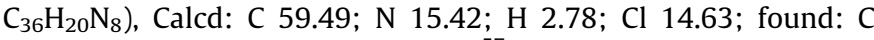
58.29; N 15.22; H 2.63; Cl 14.06. (b) ${ }^{57} \mathrm{Fe}$ Mössbauer ( $77 \mathrm{~K}$, relative to $\alpha$-iron): IS $=1.15 \mathrm{~mm} \mathrm{~s}^{-1}, \mathrm{QS}=3.28 \mathrm{~mm} \mathrm{~s}^{-1}, \Gamma=0.34 \mathrm{~mm} \mathrm{~s}^{-1}$.

\subsection{DNA interaction experiments}

Lyophilized calf thymus DNA (Fluka, BioChemika) was resuspended in $1.0 \times 10^{-3} \mathrm{M}$ Tris- $\mathrm{HCl}$ pH 7.5 and dialyzed as described in the literature [23]. DNA concentration, expressed in monomer units $\left(\left[D_{N A} A_{\text {phosphate }}\right]=1.0 \times 10^{-3} \mathrm{M}\right)$, was determined by UV spectrophotometry using the molar absorption coefficient $7000 \mathrm{M}^{-1}$ $\mathrm{cm}^{-1}$ at $258 \mathrm{~nm}$ [24].

All experiments were carried in Tris- $\mathrm{HCl}$ aqueous solution at $\mathrm{pH}$ 6.5. Temperature dependent UV-visible (UV-vis) absorption measurements were performed on a Varian UV-vis Cary 1E double beam spectrophotometer, equipped with a Peltier temperature controller, using $1 \mathrm{~cm}$ path-length quartz suprasil cuvettes, with buffer compensation. Circular dichroism (CD) spectra were recorded at $25{ }^{\circ} \mathrm{C}$ on a Jasco J-715 spectropolarimeter, using $1 \mathrm{~cm}$ path-length quartz suprasil cuvettes, with buffer compensation. Fluorescence spectral changes were registered, at room temperature, in the range $200-1100 \mathrm{~nm}$ on samples excited by a Deuterium lamp (Avalight-DHS) in the frequency range $200-400 \mathrm{~nm}$ using an Avaspec-2048 spectrometer.

\section{Results and discussion}

\section{1. ${ }^{57} \mathrm{Fe}$ Mössbauer spectroscopy}

The isomer shift of the ${ }^{57} \mathrm{Fe}$ Mössbauer spectrum of $[\mathrm{Fe}(\mathrm{dppz})] \mathrm{Cl}_{3}$ is typical of high spin $\mathrm{Fe}^{\mathrm{III}}$ compounds [25]. In combination with the results of the elemental analysis a tbp coordination geometry can be hypothesized in the solid state for the

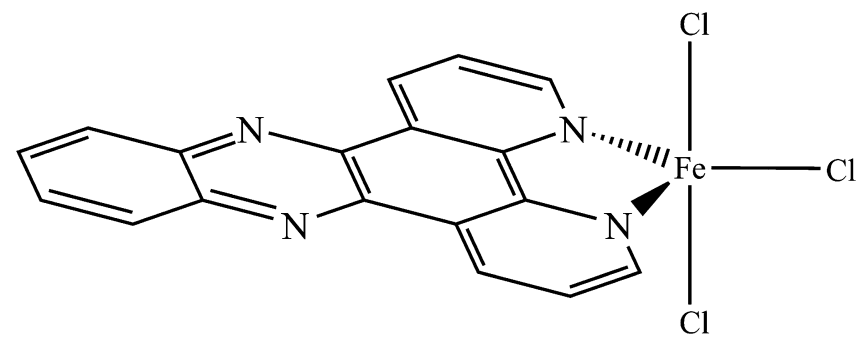

Scheme 2. Possible structure of the $\left[\mathrm{Fe}^{\mathrm{III}} \mathrm{dppz}\right] \mathrm{Cl}_{3}$ complex. 
[Fe(dppz) $] \mathrm{Cl}_{3}$ complex, with the nitrogen atoms 3 and 4 of the ligand in equatorial position (see Scheme 2 ).

The isomer shift of the $\left[\mathrm{Fe}(\mathrm{dppz})_{2}\right] \mathrm{Cl}_{3}$ complex is also typical of high spin $\mathrm{Fe}^{\mathrm{III}}$ [25] while, on the other hand, the value of the quadrupole splitting parameter is indicative of a different coordination geometry, possibly trans- $\mathrm{Cl}_{2}$-octahedral $\left[\mathrm{Fe}(\mathrm{dppz})_{2} \mathrm{Cl}_{2}\right]^{+}$, in analogy to what found for $\left[\mathrm{Cr}(\mathrm{dppz})_{2} \mathrm{Cl}_{2}\right]^{+}[13]$.

\subsection{Characterization of $[\mathrm{Fe}(\mathrm{dppz})] \mathrm{Cl}_{3}$ in solution}

The dppz ligand is sparingly soluble in water. As a consequence, it was not possible to perform potentiometric studies to determine the basic strength of the nitrogen atoms 4 and 5 in water (see Scheme 1). On the other hand, dppz is soluble in ethanol and its UV-vis spectrum is shown in Fig. 1.

It is worth to note that the UV-vis spectrum of the ligand shows characteristic peaks at 249 and $270 \mathrm{~nm}$, a shoulder at $290 \mathrm{~nm}$, and a multiplet in the range $325-400 \mathrm{~nm}$, the latter interpreted as a $\pi-$ $\pi^{*}$ transition $[4,5]$.

On the other hand, $[\mathrm{Fe}(\mathrm{dppz})] \mathrm{Cl}_{3}$ is soluble in water but its stability is limited by hydrolysis phenomena. In $(1.0 \pm 0.1) \cdot 10^{-4} \mathrm{M}$ solutions the $\mathrm{pH}$ is 3.6 and the molar conductivity $\Lambda_{\mathrm{M}}$ is equal to $1550 \Omega^{-1} \mathrm{~cm}^{2} \mathrm{~mol}^{-1}$, at $21.0^{\circ} \mathrm{C}$. This behavior is not unexpected, because the free $\mathrm{Fe}^{3+}$ aquo ion has a strong tendency to hydrolyze to form $\mathrm{Fe}\left(\mathrm{H}_{2} \mathrm{O}\right)_{6-y}(\mathrm{OH})_{y}^{3-y}(\mathrm{y} \leqslant 4)$ species [26]. Dinuclear oxo bridged species seem to be also present in acid solutions at iron concentration higher than $10^{-3} \mathrm{M}$ (see e.g. $[27,28]$ ). The equilibrium $\mathrm{Fe}(\mathrm{III})$ hydrolysis constants at $25^{\circ} \mathrm{C}$ have been extensively studied. The hydrolysis constants in acid solutions and the hydrolysis products have been well characterized and it can be concluded that the predominant species in the $\mathrm{pH}$ range $5-7$ is the monocationic $\mathrm{Fe}\left(\mathrm{H}_{2} \mathrm{O}\right)_{4}(\mathrm{OH})_{2}^{+}$[26].

A potentiometric titration of a $1.0 \times 10^{-4} \mathrm{M}$ solution of the complex in bidistilled water has been performed at $25^{\circ} \mathrm{C}$, by a standardized $0.01 \mathrm{M} \mathrm{NaOH}$ solution, to determine the nature of the hydrolysis products of $[\mathrm{Fe}(\mathrm{dppz})] \mathrm{Cl}_{3}$ as a function of $\mathrm{pH}$. However, the titration was stopped at $\mathrm{pH} \mathrm{7,} \mathrm{due} \mathrm{to} \mathrm{the} \mathrm{formation} \mathrm{of} \mathrm{a}$ deep red precipitate. The rate of hydrolysis of the complex is in fact $\mathrm{pH}$ dependent and increases with the increase of $\mathrm{pH}$. In any case, at a $\mathrm{pH}$ value of 6.5 , the solution was clear and stable. For this reason, we have performed the study of the interaction of the $\mathrm{Fe}^{\mathrm{III}} \mathrm{dppz}$ complex with native DNA by fixing the $\mathrm{pH}$ at 6.5 (see below). At this $\mathrm{pH}$ value, it is possible to speculate that the predominant

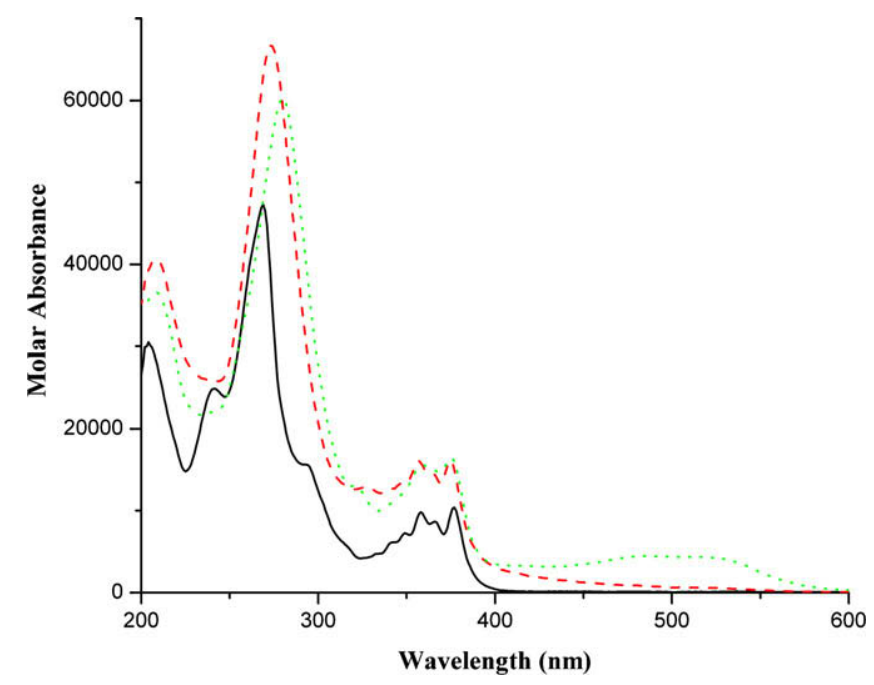

Fig. 1. UV-vis absorption spectra of dppz $10.0 \mu \mathrm{M}$ in absolute ethanol (-), $\mathrm{Fe}^{\mathrm{III}} \mathrm{dppz}$ $10.0 \mu \mathrm{M}$ in absolute ethanol ( $=-\mathrm{m})$ and $34.2 \mu \mathrm{M}$ in aqueous solution (...). species is $\left[\mathrm{Fe}(\mathrm{dppz})(\mathrm{OH})_{2}\left(\mathrm{H}_{2} \mathrm{O}\right)_{2}\right]^{+}$. In fact, the stability of the [Fe $\left.\left(\mathrm{H}_{2} \mathrm{O}\right)_{4}(\mathrm{OH})_{2}\right]^{+}$species should be slightly enhanced by the chelating $\mathrm{N}, \mathrm{N}$ ligand, because the introduction of two $\pi$-acceptor pyridine groups considerably slows down hydrolysis, and a larger $\mathrm{pH}$ stability window can therefore be accessed [29]. Considerations on the influence of $\mathrm{N}, \mathrm{N}$ ligand type on hydrolysis rate of Osmium(II) complexes have shown the crucial role of multi-ring conjugated systems such as phen or dppz [29].

The UV-vis spectra of [Fe(dppz)]Cl $\mathrm{Cl}_{3}$, see Fig. 1 , both in aqueous and in ethanol solutions, show peaks at about 375, 360, 320 and $275 \mathrm{~nm}$. In aqueous solution these peaks are only slightly broadened. A comparison with the spectrum of the dppz ligand shows that the main features of the ligand spectrum are maintained and, in particular, that the characteristic peaks of the ligand in the range $325-400 \mathrm{~nm}$ are broadened and overlapped in the presence of the metal. As a consequence, the latter can be attributed to a metal perturbed infra-ligand (IL) electronic transition. Moreover, there is a weak and broad signal in the range $450-550 \mathrm{~nm}$, absent in ethanol solution, that can be assigned to $d-d$ transitions.

The attempt to dissolve the $\left[\mathrm{Fe}(\mathrm{dppz})_{2}\right] \mathrm{Cl}_{3}$ complex in aqueous solution has provided further information on the nature and stability of the $\mathrm{Fe}^{\mathrm{III}} \mathrm{dppz}$ complexes. In fact, by dissolving the $\left[\mathrm{Fe}(\mathrm{dppz})_{2}\right] \mathrm{Cl}_{3}$ in water, a rapid formation of a yellowish solid occurred, while the solution became deep red, a color very similar to the $[\mathrm{Fe}(\mathrm{dppz})] \mathrm{Cl}_{3}$ solutions. Moreover, the UV-vis spectrum of the supernatant was identical to that of $[\mathrm{Fe}(\mathrm{dppz})] \mathrm{Cl}_{3}$. These evidences allowed us to conclude that $\left[\mathrm{Fe}(\mathrm{dppz})_{2}\right] \mathrm{Cl}_{3}$ is not stable in water solution, and one leaving dppz ligand precipitates from the aqueous solution, possibly replaced by two coordinating water molecules. In conclusion, it can be stated that only one species is present in aqueous solution at $\mathrm{pH} 6.5$, presumably the above mentioned cationic octahedral complex $\left[\mathrm{Fe}(\mathrm{dppz})(\mathrm{OH})_{2}\left(\mathrm{H}_{2} \mathrm{O}\right)_{2}\right]^{+}$.

Of course, this behavior is not observed while studying $\mathrm{Fe}(\mathrm{II})(-$ phen $)_{2} \mathrm{dppz}[7,8]$ or the analogous $\mathrm{Ru}^{\mathrm{II}}$ complexes [5]. In fact, the concomitant coordination by phenantroline and dppz fills all the metal coordination sites, preventing the occurrence of hydrolysis and stabilizing the charged cationic complex and the $2+\left(\mathrm{Fe}^{\mathrm{II}}\right)$ iron oxidation state.

\section{Interaction of $\mathrm{Fe}^{\mathrm{III}} \mathrm{dppz}$ with DNA}

\subsection{UV-vis absorption spectroscopy}

The UV-vis absorption spectrum (Fig. 2) of the Fe ${ }^{\mathrm{III}} \mathrm{dppz}$ complex is significantly perturbed by the addition of increasing amounts of DNA. In details, the absorption band of the complex at $375 \mathrm{~nm}$ (solid line in Fig. 2) is red shifted by about $4 \mathrm{~nm}$ and shows hypochromism of about 30\% (see inset in Fig. 2). Moreover, the intensity of the absorption band at $270 \mathrm{~nm}$ (solid line) is lowered by the addition of DNA in the range $0 \leqslant\left[D_{N A} A_{\text {phosphate }}\right] /$ $\left[\mathrm{Fe}^{\mathrm{III}} \mathrm{dppz}\right] \leqslant 0.65$, while it increases at higher molar ratios.

In general, the absorption spectra of metal complexes bound to DNA through intercalation exhibit significant hypochromism and red shift due to the strong $\pi-\pi$ stacking interaction between the aromatic chromophore ligand of metal complex and the base pairs of DNA $[5,6,8,10,11]$. It is well known that the hypochromic effect following the DNA-intercalation of the dppz ligand of a metal complex is due to the coupling of its $\pi^{*}$ orbital with the $\pi$ orbital of DNA base pairs [7]. In fact, the transition probability decreases because the coupled $\pi^{*}$ orbital of the dppz ligand of the metal complex is partially occupied due to overlapping with the $\pi$ orbital of the DNA base pairs [7]. Furthermore, this coupling leads to a decrease of the $\pi-\pi^{*}$ transition energy hence to a red shift of the $\lambda_{\max }$ of the IL transition. Moreover, the presence of an isosbestic point at $380 \mathrm{~nm}$ is indicative of the existence of equilibrium between two 


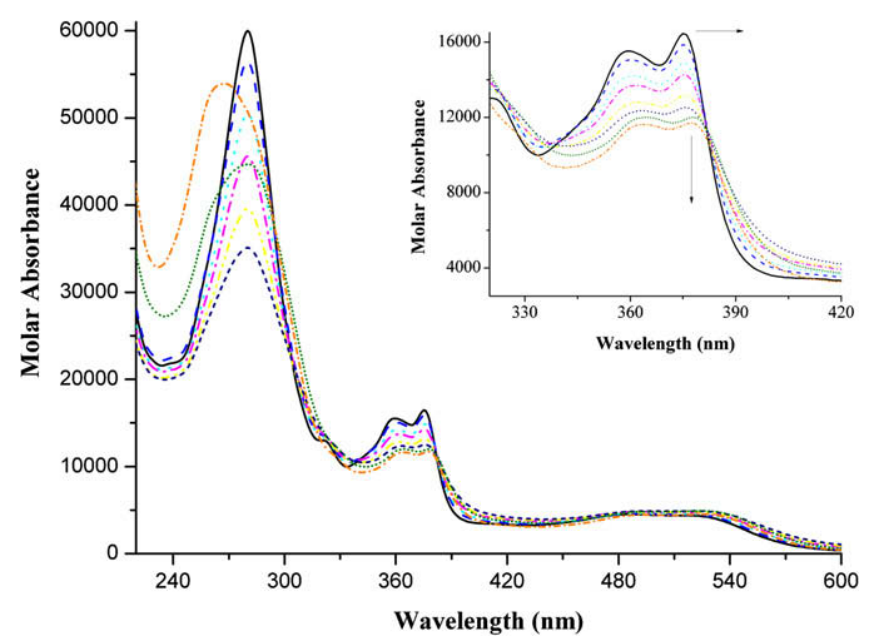

Fig. 2. Representative UV-vis absorption spectra of $\mathrm{Fe}^{\mathrm{III}} \mathrm{dppz}$ in the presence of increasing amount of CT-DNA in Tris-HCl $1.0 \times 10^{-3} \mathrm{M}$. [Fe $\left.\mathrm{Fe}^{\mathrm{III}} \mathrm{dppz}\right]=34.2 \mu \mathrm{M}$, $\left[\mathrm{DNA}_{\text {phosphate }}\right] /\left[\mathrm{Fe}^{\mathrm{III}} \mathrm{dppz}\right]=0.00(-), 0.15(-\mathrm{m}=), 0.25(\bullet \bullet), 0.35(=\bullet=), 0.45$ $(-), 0.65(--+), 1.05(\bullet \bullet)$ and $2.63\left({ }^{\circ} \cdot\right)$.

species in solutions, being possibly $\mathrm{Fe}^{\mathrm{III}} \mathrm{dppz}$ free and bound to DNA. Noteworthy, analogous spectral changes, registered for several metal complexes with the dppz ligand, have been all interpreted in terms of DNA-intercalation of the polycyclic aromatic ligand $[5,6,8,10,11]$.

To determine the intrinsic binding constant $\left(K_{\mathrm{b}}\right)$ and the stoichiometry of the Fe ${ }^{\mathrm{III}} \mathrm{dppz}-\mathrm{DNA}$ system, the quantity $\left(a^{*}-\varepsilon_{\mathrm{f}}\right) /\left(\varepsilon_{\mathrm{b}}-\varepsilon_{\mathrm{f}}\right)$ at $375 \mathrm{~nm}$ has been plotted, in Fig. 3, as a function of the molar concentration of DNA, in monomeric units (DNA $\mathrm{Dhoshate}) . \varepsilon_{\mathrm{f}}, \varepsilon_{\mathrm{b}}$ and $a^{*}$ are, respectively, the molar extinction coefficients of free $\mathrm{Fe}^{\mathrm{III}} \mathrm{dppz}$, of $\mathrm{Fe}^{\mathrm{III}} \mathrm{dppz}$ bound to DNA and of the solution containing both free and bound $\mathrm{Fe}^{\mathrm{III}} \mathrm{dppz}$.

In particular, $\varepsilon_{\mathrm{f}}$, equal to $1.65 \times 10^{4} \mathrm{M}^{-1} \mathrm{~cm}^{-1}$, was determined by a calibration curve of the isolated metal complexes in aqueous solution, following the Beer-Lambert law. $\varepsilon_{\mathrm{b}}$, equal to $1.13 \times$ $10^{4} \mathrm{M}^{-1} \mathrm{~cm}^{-1}$, was determined from the plateau of the DNA titration, where addition of DNA did not result in further changes in the absorption spectrum. Finally, $a^{*}$ was determined as the ratio between the measured absorbance and the $\mathrm{Fe}^{\mathrm{III}} \mathrm{dppz}$ analytical molar concentration.

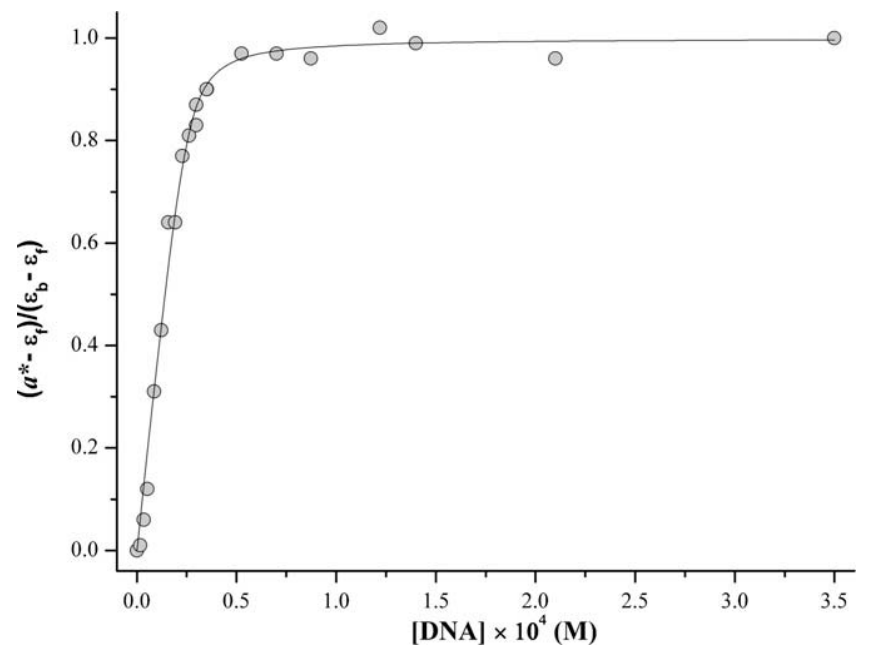

Fig. 3. Spectrophotometric titration of $\mathrm{Fe}^{\mathrm{III}} \mathrm{dppz}$, at $375 \mathrm{~nm}$, with CT-DNA in aqueous solution. [ $\left.\mathrm{Fe}^{\mathrm{III}} \mathrm{dppz}\right]=34.2 \mu \mathrm{M}$, [DNA $\left.\mathrm{Dh}_{\text {phoshate }}\right]=0.0-350 \mu \mathrm{M}$. The solid line is the fit of the experimental data by Eq. (1).
Using Eq. (1) [30,31], we obtained the values of the intrinsic binding constant $\left(K_{\mathrm{b}}\right)$ and of the binding size in base pairs $(s)$ of the Fe ${ }^{\text {III }} \mathrm{dppz}-\mathrm{DNA}$ complex:

$$
\begin{aligned}
& \frac{a^{*}-\varepsilon_{\mathrm{f}}}{\varepsilon_{\mathrm{b}}-\varepsilon_{\mathrm{f}}}=\frac{b-\left(b^{2} \frac{2 K_{\mathrm{b}}^{2} C_{\mathrm{t}}\left[\mathrm{DNA}_{\text {phosphate }}\right]}{s}\right)^{1 / 2}}{2 K_{\mathrm{b}} C_{\mathrm{t}}} \\
& b=1+K_{\mathrm{b}} C_{\mathrm{t}}+\frac{K_{\mathrm{b}}\left[\mathrm{DNA}_{\text {phosphate }}\right]}{2 s}
\end{aligned}
$$

where $C_{\mathrm{t}}$ is the total concentration of the metal complex. The $K_{\mathrm{b}}$ and $s$ values, obtained by nonlinear fitting of the experimental data by Eq. (1), are $K_{\mathrm{b}}=(6.43 \pm 0.05) \times 10^{5} \mathrm{M}^{-1}$ and $s=0.36 \pm 0.01$ (see Table 2 ). The comparison of the $K_{\mathrm{b}}$ value with that of some dppz-based intercalating complexes (see Table 1 ), in particular that relative to $\left[\mathrm{Fe}(\mathrm{phen})_{2} \mathrm{dppz}\right]^{2+}[7,8]$, suggests that the strength of the DNAintercalation is significantly influenced by the presence of the dppz ligand in the metal complex while less marked effects are determined by the nature of the metal ion and of the ancillary ligands.

The value of $s$, indicating a stoichiometry of approximately $1 \mathrm{~mol}$ of DNA base pairs per $3 \mathrm{~mol}$ of metal complex, supports the hypothesis of additional interaction mechanisms, besides the DNA-intercalation.

It must be pointed out that values of $s$ smaller than unity are not uncommon, and similar values have been found for metal complexes-DNA systems with ascertained DNA intercalating interaction [30,31,35], also possibly showing other interaction mechanisms besides DNA-intercalation. However, the physical interpretation of this parameter is still a matter of debate [35].

For example, Haq et al. [35] have found two different values of $s$ for the $\Delta$ and $\Lambda$ enantiomers of the $\left[R u(p h e n)_{2} \mathrm{dppz}\right]^{2+}$ complex interacting with DNA. The first value corresponds to a 1:3 complex-to-DNA base pair molar ratio, while the second one occurs at a drug mole fraction of 0.58 for $\Delta-\left[R u(p h e n)_{2} d p p z\right]^{2+}$ and of 0.68 for $\Lambda$-[Ru(phen $\left.)_{2} \mathrm{dppz}\right]^{2+}$. The authors conclude that there is a second mode of binding corresponding to 1.4 and $2.1 \mathrm{~mol}$, respectively, of complex bound per mole of base pair. The exact nature of the binding mode that produces this unusual stoichiometry cannot be inferred from these studies alone, but it could result from self-stacking of the metal complex molecules on the DNA surface. In a similar way, Hiort et al. [5] hypothesized the existence of a second binding mode with lower affinity, based on luminescence titration experiments, consistent with a $s$ value smaller than one. Analogously, the $s$ value found in the present study by the spectrophotometric titration seems to be also representative of a weaker interaction with DNA, while the stoichiometry that describes the intercalation mechanism, obtained by fluorescence spectroscopic titration (see below), approximately corresponds to a 2:3 metal complex-DNA base pairs molar ratio.

Table 1

\begin{tabular}{|c|c|c|c|}
\hline Complex & $K_{\mathrm{b}}\left(\mathrm{M}^{-1}\right)$ & $s$ & References \\
\hline$\left[\mathrm{Ru}\left(\mathrm{NH}_{3}\right)_{4} \mathrm{dppz}\right]^{2+}$ & $1.24 \times 10^{5}$ & 0.02 & [11] \\
\hline$\left[\mathrm{Ru}(\mathrm{phen})_{2} \mathrm{dppz}\right]^{2+}$ & $5.1 \times 10^{6}$ & 0.6 & [11] \\
\hline cis- $\left[\mathrm{Rh}_{2}\left(\mu-\mathrm{O}_{2} \mathrm{CCH}_{3}\right)_{2} \mathrm{dppz}\left(\eta^{1}-\mathrm{O}_{2} \mathrm{CCH}_{3}\right)\left(\mathrm{CH}_{3} \mathrm{OH}\right)\right]$ & $4.4 \times 10^{5}$ & 2.1 & [32] \\
\hline cis- $\left[\mathrm{Rh}_{2}\left(\mu-\mathrm{O}_{2} \mathrm{CCH}_{3}\right)_{2}(\mathrm{dppz})_{2}\right]^{2}$ & $7.0 \times 10^{6}$ & 0.9 & [32] \\
\hline$\left[\mathrm{Ru}(\operatorname{Im})_{4} \mathrm{dppz}\right]^{2+}$ & $2.5 \times 10^{6}$ & 2.18 & {$[12]$} \\
\hline$\left[\mathrm{Ru}(\mathrm{MeIm})_{4} \mathrm{dppz}\right]^{2+}$ & $1.1 \times 10^{6}$ & 1.44 & [12] \\
\hline$\left[\mathrm{Au}(\mathrm{dppz})_{2}\right] \mathrm{Cl}_{3}$ & $1.8 \times 10^{5}$ & - & [9] \\
\hline$\left[\mathrm{Cu}(\mathrm{dppz})_{2} \mathrm{Cl}\right] \mathrm{Cl}$ & $2.0 \times 10^{4}$ & - & [1] \\
\hline$\left[\mathrm{Fe}(\mathrm{phen})_{2} \mathrm{dppz}\right]^{2+}$ & $1.52 \times 10^{5}$ & - & {$[7,8]$} \\
\hline$\left[\mathrm{Os}(\mathrm{bpy})_{2} \mathrm{dppz}\right]^{2+}$ & $4.2 \times 10^{6}$ & 0.7 & [33] \\
\hline$\left[\mathrm{Co}(\text { phen })_{2} \mathrm{dppz}\right]^{3+}$ & $7.6 \times 10^{6}$ & - & [6] \\
\hline$\left[\mathrm{Cr}(\mathrm{dppz})_{2} \mathrm{Cl}\right]^{+}$ & $1.8 \times 10^{7}$ & - & [13] \\
\hline$\left[\mathrm{Cr}(\mathrm{phen})_{2} \mathrm{dppz}\right]^{3+}$ & $3.0 \times 10^{5}$ & - & [4] \\
\hline$\left[\mathrm{Ru}(\mathrm{IP})_{2} \mathrm{dppz}\right]^{2+}$ & $2.1 \times 10^{7}$ & 0.4 & [34] \\
\hline
\end{tabular}

$K_{\mathrm{b}}$ and $s$ values of some dppz-based complexes interacting with CT-DNA 


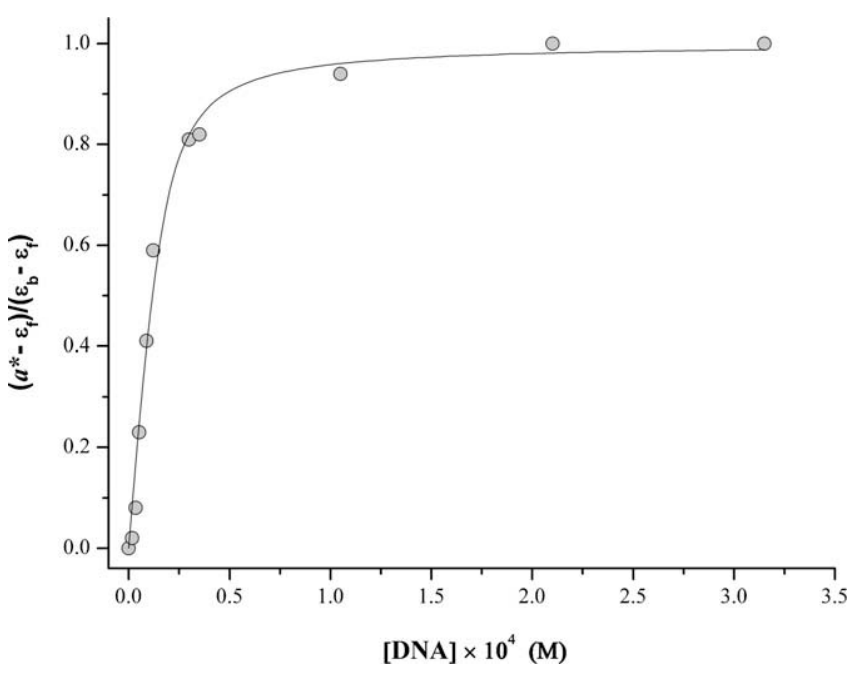

Fig. 4. Spectrophotometric titration of $\mathrm{Fe}^{\mathrm{III}} \mathrm{dppz}$, at $375 \mathrm{~nm}$, with $\mathrm{CT}-\mathrm{DNA}$ in aqueous solution. $\left[\mathrm{Fe}^{\mathrm{III}} \mathrm{dppz}\right]=33.2 \mu \mathrm{M}, \quad\left[\mathrm{DNA}_{\text {phosphate }}\right]=0.0-315 \mu \mathrm{M}$ and $[\mathrm{NaCl}]=2 \mathrm{mM}$. The solid line is the fit of the experimental data by Eq. (1).

To verify the effect of ionic strength on the interaction, we have recorded the UV-vis spectra of $\mathrm{Fe}^{\mathrm{III}} \mathrm{dppz}-\mathrm{DNA}$ systems in the presence of $\mathrm{NaCl} 2 \mathrm{mM}$ (a), $10 \mathrm{mM}$ (b) and $50 \mathrm{mM}$ (c), respectively. Interestingly, while at $[\mathrm{NaCl}]=2$ and $10 \mathrm{mM}$ there are no significant variations of the shape and of the general trend with increasing the DNA concentration (e.g. hypochromism and red shift are unchanged) at $[\mathrm{NaCl}]=50 \mathrm{mM}$ all the peculiar variations attributable to DNA-intercalation are lost. Moreover, in the latter case, the formation of a gelatinous precipitate occurs after few hours of the sample preparation. The spectrophotometric titration curves of $\mathrm{Fe}^{\mathrm{III}} \mathrm{dppz}-\mathrm{DNA}$ system in the presence of $\mathrm{NaCl} 2 \mathrm{mM}$ (a) and $10 \mathrm{mM}$ (b) are reported in Figs. 4 and 5, while the corresponding values of $K_{\mathrm{b}}$ and $s$ are reported in Table 2 .

It must be noted that the binding affinity of $\mathrm{Fe}^{\mathrm{III}} \mathrm{dppz}$ toward DNA shows an initial rapid decrease in the range $0 \leqslant[\mathrm{NaCl}] \leqslant$ $2 \mathrm{mM}$ followed by a nearly constant value at higher $\mathrm{NaCl}$ concentration. This trend, together with the decrease of $s$ and the occurrence of DNA precipitation at the higher ionic strength investigated, suggests that a strong electrostatic interaction between the $\mathrm{Fe}^{\mathrm{III}} \mathrm{dppz}$ cation and DNA is taking place in addition to the ascer-

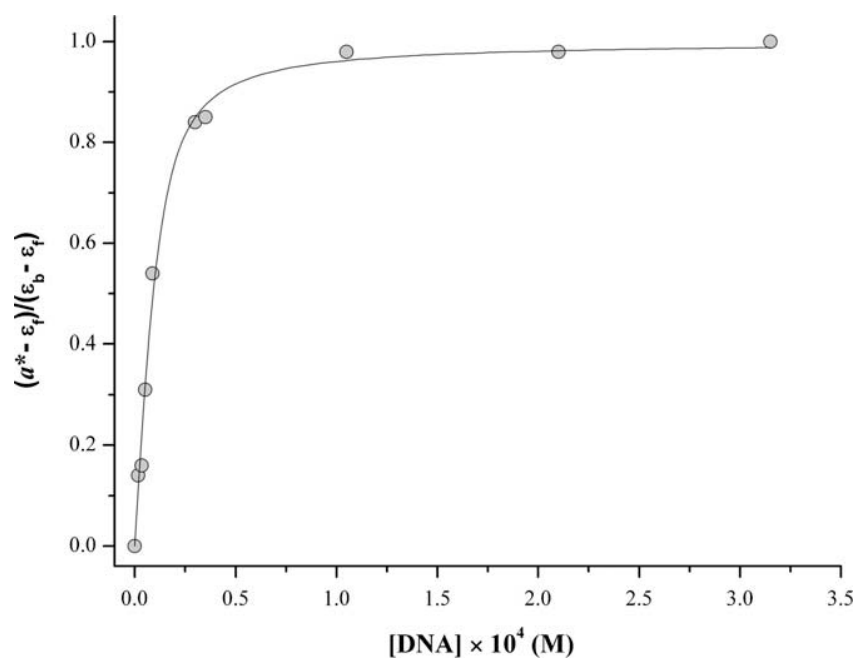

Fig. 5. Spectrophotometric titration of $\mathrm{Fe}^{\mathrm{III}} \mathrm{dppz}$, at $375 \mathrm{~nm}$, with CT-DNA in aqueous solution. $\left[\mathrm{Fe}^{\mathrm{III}} \mathrm{dppz}\right]=33.2 \mu \mathrm{M}, \quad\left[\mathrm{DNA}_{\text {phosphate }}\right]=0.0-315 \mu \mathrm{M}$ and $[\mathrm{NaCl}]=10 \mathrm{mM}$. The solid line is the fit of the experimental data by Eq. (1).
Table 2

Values of $K_{\mathrm{b}}$ and $s$ at different ionic strength

\begin{tabular}{llll}
\hline & $\begin{array}{l}\mathrm{Fe}(\mathrm{III}) \mathrm{dppz}-\mathrm{DNA} \\
([\mathrm{NaCl}]=0 \mathrm{mM})\end{array}$ & $\begin{array}{l}\mathrm{Fe}(\mathrm{III}) \mathrm{dppz}-\mathrm{DNA} \\
([\mathrm{NaCl}]=2 \mathrm{mM})\end{array}$ & $\begin{array}{l}\mathrm{Fe}(\mathrm{III}) \mathrm{dppz}-\mathrm{DNA} \\
([\mathrm{NaCl}]=10 \mathrm{mM})\end{array}$ \\
\hline$K_{\mathrm{b}}\left(\mathrm{M}^{-1}\right)$ & $(6.43 \pm 0.05) \times 10^{5}$ & $(1.31 \pm 0.01) \times 10^{5}$ & $(9.0 \pm 0.1) \times 10^{4}$ \\
$s$ & $0.36 \pm 0.01$ & $0.24 \pm 0.01$ & $0.16 \pm 0.01$ \\
\hline
\end{tabular}

tained intercalative binding. In fact, the latter interaction is reduced by the presence of sodium counterions in solution, that shield the attraction between $\mathrm{Fe}^{\mathrm{III}} \mathrm{dppz}$ and the negatively charged phosphate groups of DNA [36].

\subsection{DNA thermal denaturation analysis}

Thermal denaturation profiles of calf thymus DNA solutions, in the presence of increasing amounts of $\mathrm{Fe}^{\mathrm{IIII}} \mathrm{dppz}$, were obtained by plotting the absorbance at $258 \mathrm{~nm}$ as a function of temperature (see Fig. 6).

It is known that when the temperature is increased, the doublestranded DNA gradually dissociates into single strands. The DNA melting temperature $\left(T_{\mathrm{m}}\right)$ is therefore defined as the temperature where half of the total base pairs are unpaired [37]. $T_{\mathrm{m}}$ is strictly related to the stability of the double helix, and the interaction of chemicals with DNA may alter $T_{\mathrm{m}}$, by various stabilizing or destabilizing effects. Moreover, it is also possible to obtain information on the nature and strength of the interaction. According to the literature [38-40], the intercalation of natural or synthesized compounds results in the stabilization of the DNA double helix, due to stacking interactions, emphasized by a considerable increase in the melting temperature of DNA. The presence of a positive charge on the intercalator further increases the attractive interaction with the negatively charged phosphate groups and assists the intercalative mechanism. The melting temperature of DNA $100 \mu \mathrm{M}$ in Tris- $\mathrm{HCl} 1 \mathrm{mM}$ (Fig. 6) increases of about 18 and $19^{\circ} \mathrm{C}$, at $\left[\mathrm{Fe}^{\mathrm{III}} \mathrm{dppz}\right] /\left[\mathrm{DNA}_{\text {phosphate }}\right]$ molar ratios 0.25 and 0.50 , respectively. These results are indicative of a strong metal complex-DNA interaction that stabilizes the native DNA conformation. Moreover, the tiny difference in the $T_{\mathrm{m}}$ values obtained at both molar ratios considered reveals that most of the electrostatic stabilization of DNA conformation occurs already at $\left[\mathrm{Fe}^{\mathrm{IIII}} \mathrm{dppz}\right] /\left[\mathrm{DNA}_{\text {phosphate }}\right]=$ 0.25 .

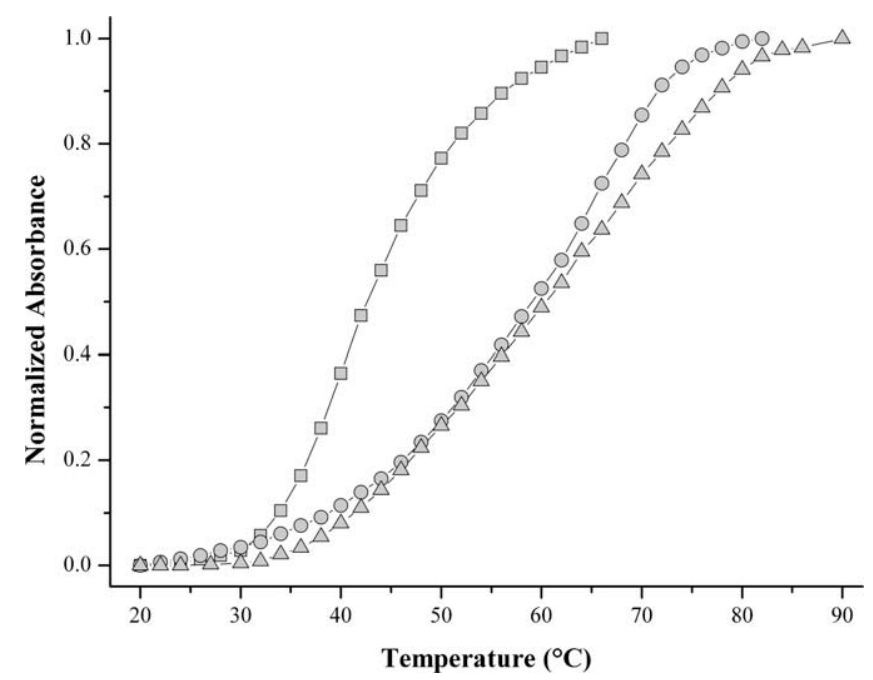

Fig. 6. Thermal denaturation profiles of CT-DNA in the presence of increasing amounts of $\mathrm{Fe}^{\mathrm{III}} \mathrm{dppz}$, in $1.0 \mathrm{mM}$ Tris-HCl. [DNA phosphate] $=100.0 \mu \mathrm{M}$; (a) $\left[\mathrm{Fe}^{\mathrm{III}} \mathrm{dppz}\right]=0.0$ (squares, $T_{\mathrm{m}}=42.6^{\circ} \mathrm{C}$ ), $25.0 \mu \mathrm{M}$ (circles, $T_{\mathrm{m}}=60.5^{\circ} \mathrm{C}$ ) and $50.0 \mu \mathrm{M}$ (triangles, $T_{\mathrm{m}}=61.1^{\circ} \mathrm{C}$ ). 


\subsection{Circular dichroism}

CD spectra of calf thymus DNA (CT-DNA) $100.0 \mu \mathrm{M}$, in $1.0 \mathrm{mM}$ Tris-HCl (Fig. 7), were recorded in the presence of increasing amounts of $\mathrm{Fe}^{\mathrm{III}} \mathrm{dppz}$ up to [Fe $\left.{ }^{\mathrm{III}} \mathrm{dppz}\right] /\left[\mathrm{DNA}_{\text {phosphate }}\right]$ molar ratios of approximately 0.9 .

The CD of native DNA (solid line in Fig. 7) is drastically modified by the addition of increasing amounts of $\mathrm{Fe}^{\mathrm{III}} \mathrm{dppz}$. In particular, the DNA dichroic band at ca. $275 \mathrm{~nm}$ (solid line in Fig. 7) is monotonously decreased to negative values of the molar ellipticity up to $\left[\mathrm{Fe}^{\mathrm{III}} \mathrm{dppz}\right]=60 \mu \mathrm{M}$, after which it slightly increases. Moreover, the positive DNA band is blue shifted of about $5 \mathrm{~nm}$. Finally, induced CD bands appear in the range $290-400 \mathrm{~nm}$. The latter result supports the existence of a tight binding between the metal complex and DNA. In fact, $\mathrm{Fe}^{\mathrm{III}} \mathrm{dppz}$ provides a further chromophore appended to the chiral backbone of the DNA double helix [41]. Interestingly, the positive band at $305 \mathrm{~nm}$ monotonously increases by following an analogous trend of the negative band at $275 \mathrm{~nm}$. The presence of five isodichroic points at about 242, 256, 294, 321 and $343 \mathrm{~nm}$ ensures that the $C D$ signals are the result of equilibrium between two species in solution, possibly the DNA and the $\mathrm{Fe}^{\mathrm{III}} \mathrm{dppz}-\mathrm{DNA}$-intercalation complex. The drastic changes observed in the $C D$ spectra, especially those at $275 \mathrm{~nm}$, could be interpreted as due to (1) the occurrence of deep conformational changes of the DNA double helix following its interaction with the metal complex, and/or to (2) linear CD effect due to the intercalated $\mathrm{Fe}^{\mathrm{III}} \mathrm{dppz}$ moiety, being both interpretations in agreement with the hypothesis of DNA-intercalation.

To perform a detailed analysis of the spectral modifications, we have plotted in Fig. 8 the values of the molar ellipticity at 305 and $273 \mathrm{~nm}$ (see Fig. 7) and the absorbance at $375 \mathrm{~nm}$ (see Fig. 2) vs. the Fe ${ }^{\text {III }} \mathrm{dppz}$ concentration. Linear trends of the molar ellipticity are clearly evident in the range $0.05<\left[\mathrm{Fe}^{\mathrm{III}} \mathrm{dppz}\right] /\left[\mathrm{DNA}_{\text {phosphate }}\right]<$ 0.60 , followed by a change in the slope at higher molar ratios. Noteworthy, the absorbance of the IL band at $375 \mathrm{~nm}$ follows the Beer-Lambert law, with a molar extinction coefficient equal to $\varepsilon_{\mathrm{b}}$ within the experimental error, suggesting that the added metal complex is totally bound to the DNA macromolecule.

The initial linear trends of Fig. 8a and $b$ as well as, apart the sign, their similarity suggest that, in the range $0.05<\left[\mathrm{Fe}^{\mathrm{III}} \mathrm{dppz}\right] /$ $\left[\mathrm{DNA}_{\text {phosphate }}\right]<0.60$, the observed behavior is mainly determined by the rigid complex intercalation in the DNA double helix, while

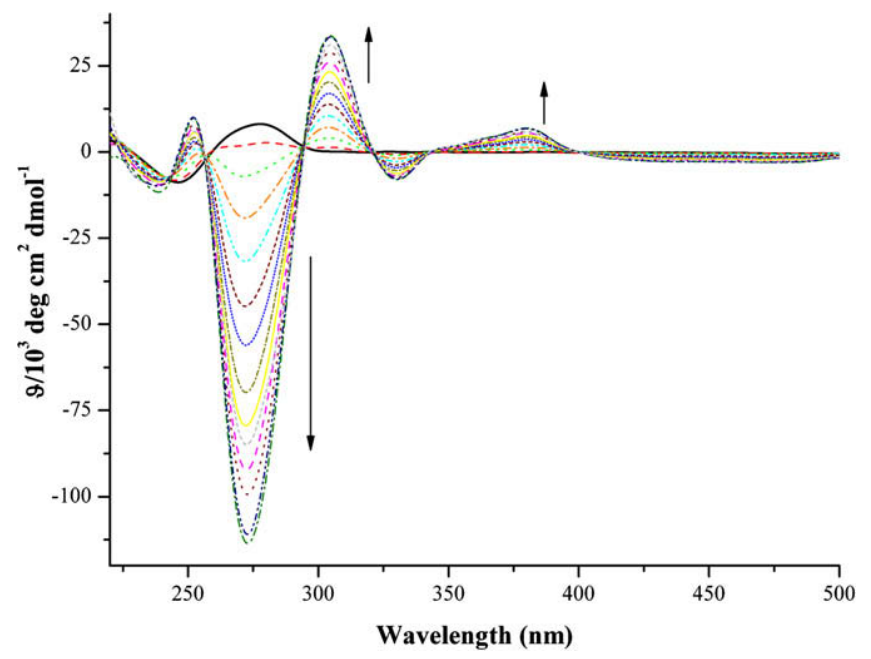

Fig. 7. Circular dichroism spectra of CT-DNA in the presence of increasing amounts of Fe $\mathrm{Fe}^{\mathrm{III}} \mathrm{dppz}$ in $1.0 \mathrm{mM}$ Tris-HCl. [DNA $\mathrm{phosphate}=100 \mu \mathrm{M},\left[\mathrm{Fe} \mathrm{eII}^{\mathrm{III}} \mathrm{dpp}\right]=0.00(-), 4.98$

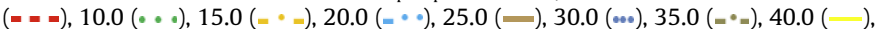

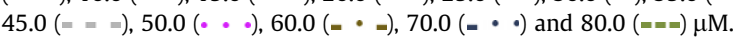
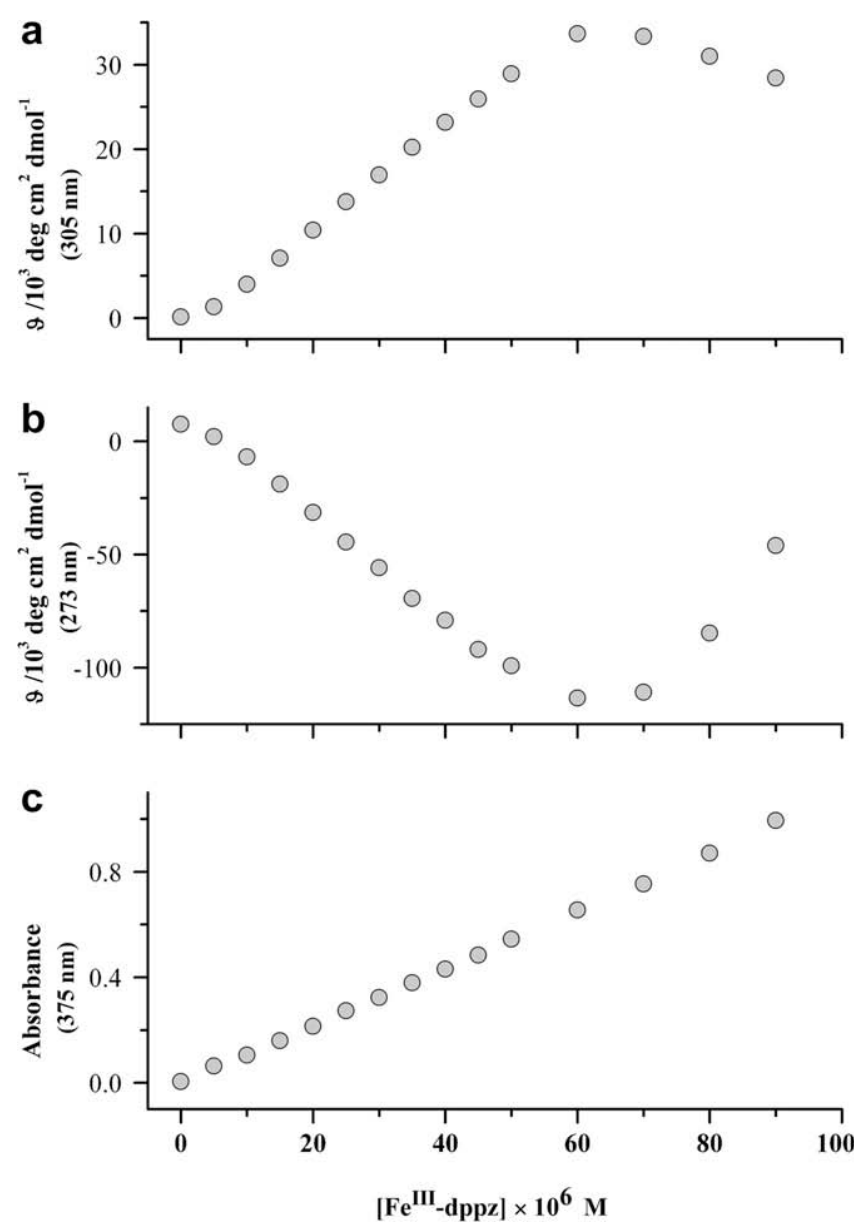

Fig. 8. Molar ellipticity at $305 \mathrm{~nm}$ (a), at $273 \mathrm{~nm}$ (b) and UV-vis absorbance at $375 \mathrm{~nm}$ (c) of $\mathrm{Fe}^{\mathrm{III}} \mathrm{dppz}-\mathrm{DNA}$ aqueous solutions in the presence of increasing amounts of Fe $\mathrm{IIII}_{\mathrm{IIp} z \text {. }}$

at $\left[\mathrm{Fe}^{\mathrm{III}} \mathrm{dppz}\right] /\left[\mathrm{DNA}_{\text {phosphate }}\right]$ higher than 0.6 that a different $\mathrm{Fe}^{\mathrm{III}} \mathrm{dppz}$-DNA-binding mode than intercalation starts. In particular, the second binding mode would be essentially electrostatic in nature, in agreement with the considerations made in the UV-vis absorption spectroscopy section, and would indicate that, through the neutralization of DNA charges, the ionic form of $\mathrm{Fe}^{\mathrm{III}} \mathrm{dppz}$ induces the formation of DNA supramolecular aggregates. Such hypothesis is also supported by the evidence of incipient DNA precipitation observed at $\left[\mathrm{Fe}^{\mathrm{III}} \mathrm{dppz}\right] /\left[\mathrm{DNA}_{\text {phosphate }}\right]$ molar ratios higher than 0.9 and at higher ionic strength. Moreover, this result can be considered a quantification of the Fe ${ }^{\text {III }} \mathrm{dppz}-\mathrm{DNA}_{\text {phosphate }}$ interaction stoichiometry. In fact, the stoichiometry of approximately $1 \mathrm{~mol}$ of DNA base pairs per $3 \mathrm{~mol}$ of metal complex, determined by spectrophotometric titration, could be considered the sum of two contributions: DNA-intercalation and electrostatic binding. Finally, the $\mathrm{CD}$ spectrum recorded in the presence of [Fe $\left.{ }^{\mathrm{III}} \mathrm{dppz}\right]$ higher than $30 \mu \mathrm{M}$ is similar to that observed for supramolecular chiral DNA aggregates [42] although, on the basis of the considerations above, in our opinion it is possible to assign such modifications to effects induced by the appended $\mathrm{Fe}^{\mathrm{III}} \mathrm{dppz}$ moiety rather than to DNA conformational changes.

\subsection{Fluorescence}

No fluorescence was observed for solutions of $\mathrm{Fe}^{\mathrm{III}} \mathrm{dppz}$ and of $\mathrm{Fe}^{\mathrm{III}} \mathrm{dppz}$-DNA. On the other hand, the intensity of the fluorescence spectrum of the EB-DNA complex is lowered by the addition of increasing amounts of $\mathrm{Fe}^{\mathrm{III}} \mathrm{dppz}$ (see Fig. 9). 
It is known that DNA solutions are not fluorescent, while a strong fluorescence emission is observed in the presence of ethidium bromide (EB) in the DNA solution. EB is also weakly fluorescent, but the EB-DNA complex is remarkably more fluorescent at about $600 \mathrm{~nm}$, as a consequence of the intercalation of EB between adjacent DNA base pairs [43].

The spectra shown in Fig. 9 indicate that the metal complex is able to displace EB from the DNA-intercalation sites and confirm that $\mathrm{Fe}^{\mathrm{III}} \mathrm{dppz}$ interacts with DNA by an intercalating mechanism, competing with EB for the same binding sites. By plotting the fluorescence intensity at $600 \mathrm{~nm}$ vs. the Fe ${ }^{\text {III }} \mathrm{dppz}$ molar concentration (see Fig. 10) a steep decrease of the signal is noticed, followed by a plateau in the presence of $\mathrm{Fe}^{\mathrm{III}} \mathrm{dppz}$ concentrations higher than $15 \mu \mathrm{M}$. Noticeably, the latter value corresponds to a [Fe $\left.{ }^{\text {III }} \mathrm{dppz}\right] /$ $\left[\mathrm{DNA}_{\text {phosphate }}\right]$ molar ratio equal to 0.60 , corresponding to the value at which the trend of the molar ellipticity vs. the Fe ${ }^{\text {III }} \mathrm{dppz}$ concentration changes slope (see Fig. 8).

These data have been interpreted by hypothesizing the existence of a competition reaction between EB and $\mathrm{Fe}^{\mathrm{III}} \mathrm{dppz}$ towards DNA-binding sites, and this treatment allowed us to estimate the

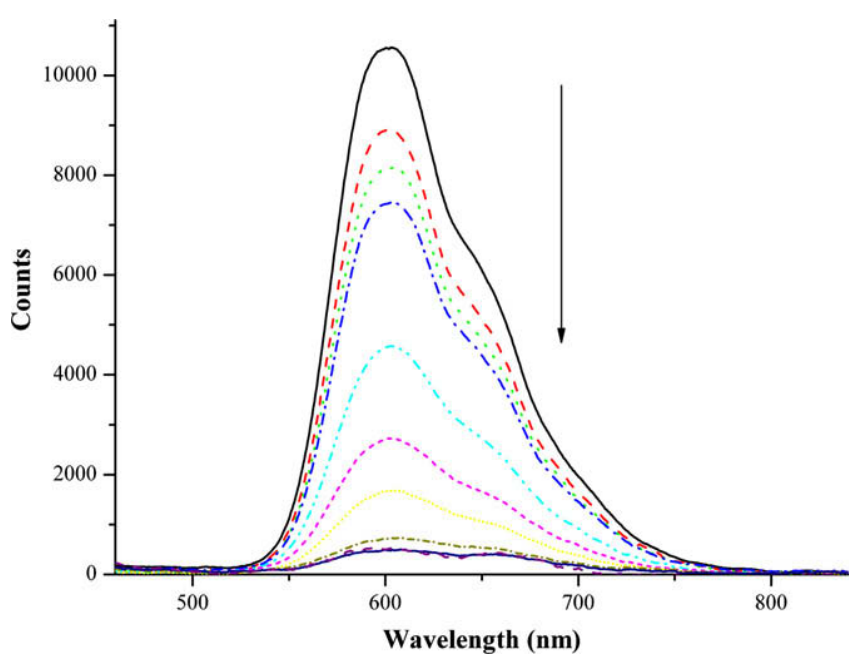

Fig. 9. Fluorescence spectra of the EB-DNA complex in the presence of increasing amounts of $\mathrm{Fe}^{\mathrm{III}} \mathrm{dppz}$. [EB] $=4.0 \mu \mathrm{M},[\mathrm{DNA}]=25.0 \mu \mathrm{M} ;\left[\mathrm{Fe}^{\mathrm{III}} \mathrm{dppz}\right]=0.00(-), 1.25$

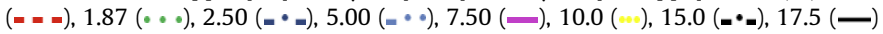
and $20.0(-=-) \mu \mathrm{M}$.

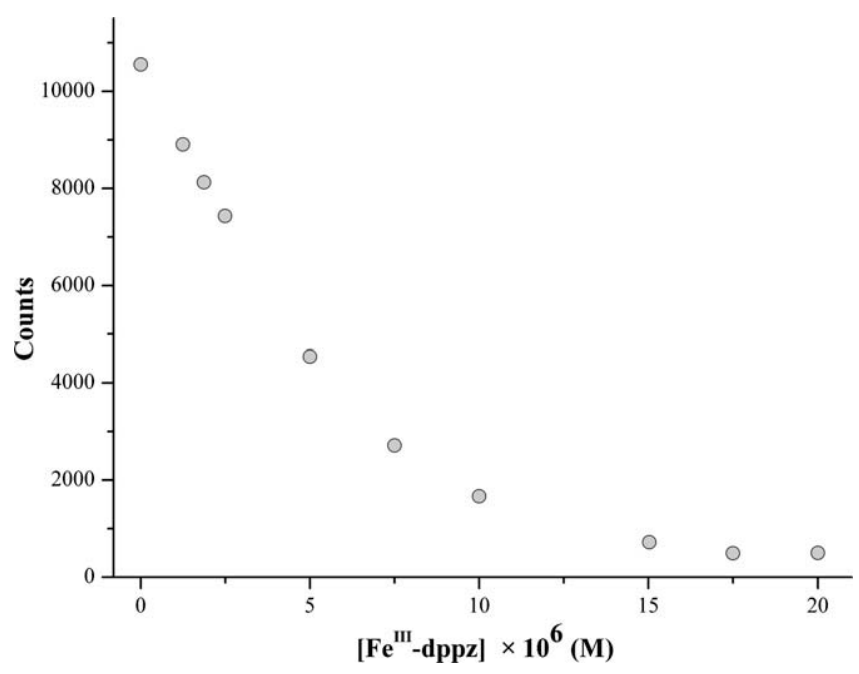

Fig. 10. Fluorescence intensity at $600 \mathrm{~nm}$ vs. the Fe $\mathrm{IIII}_{\mathrm{II}} \mathrm{dpz}$ molar concentration. value of the intrinsic intercalation binding constant (called $K_{i}$ ). If we consider EB totally bound to DNA, as known from the literature $[40,41]$, a competition reaction between $\mathrm{EB}$ and $\mathrm{Fe}^{\mathrm{III}} \mathrm{dppz}$ for intercalation into DNA is the following:

$\mathrm{EB}-\mathrm{DNA}+\mathrm{Fe}^{\mathrm{III}} \mathrm{dppz} \rightleftarrows \mathrm{EB}+\mathrm{Fe}^{\mathrm{III}} \mathrm{dppz}-\mathrm{DNA}$

If we call $E_{\mathrm{b}}$ and $E_{\mathrm{f}}$ the molar concentrations of EB bound to DNA and free, respectively, and $C_{\mathrm{b}}$ and $C_{\mathrm{f}}$ the analogous molar concentrations of $\mathrm{Fe}^{\mathrm{III}} \mathrm{dppz}$, we can express the equilibrium constant, $K$, of reaction (2) as

$K=\left(C_{\mathrm{b}} \cdot E_{\mathrm{f}}\right) /\left(E_{\mathrm{b}} \cdot C_{\mathrm{f}}\right)=K_{\mathrm{i}}\left\{\mathrm{Fe}^{\mathrm{III}} \mathrm{dppz}\right\} / K_{i}\{\mathrm{~EB}\}$

i.e. $K$ can be considered as the ratio between the equilibrium constants for the intercalation of $\mathrm{Fe}^{\mathrm{III}} \mathrm{dppz}\left(K_{i}\left\{\mathrm{Fe}^{\mathrm{III}} \mathrm{dppz}\right\}\right)$ and of $\mathrm{EB}\left(K_{i}\right.$ $\{E B\})$. Moreover, we know that the fluorescence signal $(\xi)$ is proportional to the molar concentration of EB bound to DNA $\left(E_{\mathrm{b}}\right)$ :

$\xi=$ const $\cdot E_{\mathrm{b}}$

Furthermore, if we call $s_{\mathrm{f}}$ the number of DNA base pairs available for the intercalator (we recall that two DNA monomer units are equivalent to a base pair), we can write the following mass balance equations:

$E_{\mathrm{b}}+C_{\mathrm{b}}=\left[\mathrm{DNA}_{\text {phosphate }}\right] / 2 \mathrm{~s}_{\mathrm{f}}$

$E_{\mathrm{b}}+E_{\mathrm{f}}=E_{\mathrm{t}}$

$C_{\mathrm{b}}+C_{\mathrm{f}}=C_{\mathrm{t}}$

where $E_{\mathrm{t}}$ and $C_{\mathrm{t}}$ are the analytical concentrations of EB and metal complex. Inserting Eqs. (4)-(7) into Eq. (2) we finally obtain:

$$
\begin{aligned}
C_{\mathrm{t}} \xi= & \frac{\left[\mathrm{DNA}_{\text {phosphate }}\right] \cdot E_{\mathrm{t}} \cdot \text { const }}{K \cdot 2 s_{\mathrm{f}}} \\
& +\left(\frac{\left[\mathrm{DNA}_{\text {phosphate }}\right]}{2 s_{\mathrm{f}}}-\frac{E_{\mathrm{t}}}{K}-\frac{\left[\mathrm{DNA}_{\text {phosphate }}\right]}{K \cdot 2 s_{\mathrm{f}}}\right) \xi+\frac{1}{\text { const }}\left(\frac{1}{K}-1\right) \xi^{2}
\end{aligned}
$$

By plotting $C_{t} \cdot \xi$ vs. $\xi$ we get a parabolic trend, as shown in Fig. 11.

Then, by a second order polynomial fit of the data points one can straightforwardly obtain the three parameters of the parabolic curve Eq. (8) hence of the values of $K$ and $s_{\mathrm{f}}$, equal to $6.7 \pm 0.1$ and $1.40 \pm 0.02$, respectively. By the value of $K_{\mathrm{i}}\{\mathrm{EB}\}$ reported in the literature $[44,45]$ we obtain an estimate of the value of $K_{i}\left\{\mathrm{Fe}^{\mathrm{III}} \mathrm{dppz}\right\}=(1.14 \pm 0.02) \times 10^{6} \mathrm{M}^{-1}$. A comparison between $K_{i}$ and $K_{\mathrm{b}}$ (see above) shows that they are of the same order of magnitude while the stoichiometry parameters $s$ and $s_{\mathrm{f}}$ are significantly different. We recall that the value found for $s_{\mathrm{f}}$ approximately corresponds to a 2:3 metal complex-DNA base pairs molar ratio. The differences observed might be attributable to the differences in the model systems used to obtain these values. In fact, the $K_{\mathrm{b}}$ and $s$ values were obtained by using the Carter model $[30,31]$ that does not distinguish among different kinds of metal complex-DNA interactions. On the other hand, the model chosen to analyze the fluorescence measurements focuses on the competition between $\mathrm{EB}$ and $\mathrm{Fe}^{\mathrm{III}} \mathrm{dppz}$ for the same binding sites on DNA. In conclusion, the latter model considers intercalation as the exclusive binding to DNA.

As a matter of fact, also a fluorescence quenching according to the Perrin sphere model [46] could be active, that would not imply the displacement of the DNA-intercalated EB, but instead a simple external binding of the iron complex. However, in view of the marked effects induced by Fe ${ }^{\text {III }} \mathrm{dppz}$ on the CD spectra of DNA, we are inclined to favor the former hypothesis of fluorescence quenching.

Noteworthy, there is a good agreement between the spectral changes observed in both $C D$ and fluorescence as a function of the amount of metal complex (see Figs. 8 and 10). As a conse- 


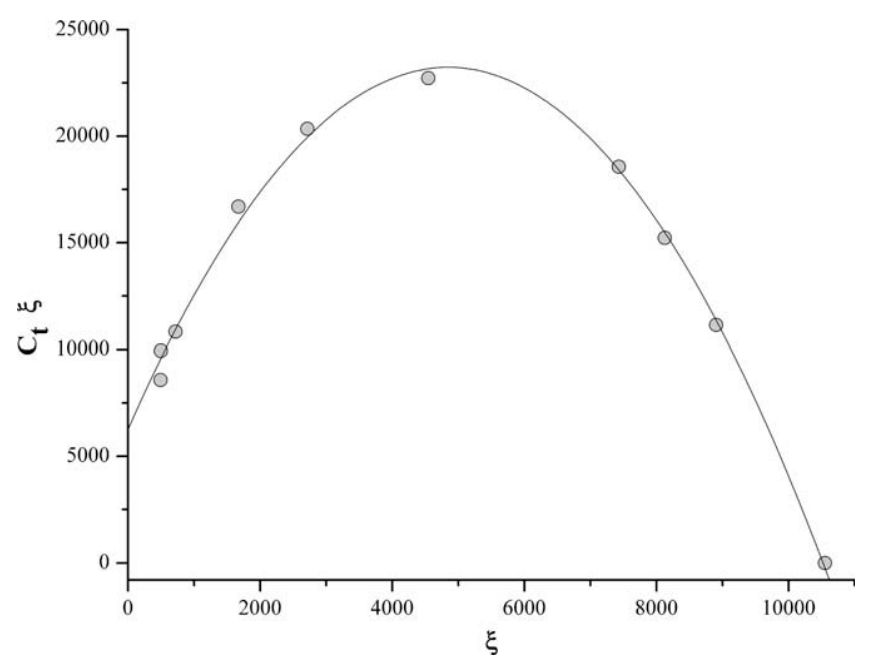

Fig. 11. Plot of $C_{\mathrm{t}} \xi$ vs. $\xi$. The solid line is a second order polynomial fit of the data.

quence, we can deduce that both techniques furnish similar values of the interaction stoichiometry relative exclusively to DNA-intercalation. It must also be pointed out that the intercalation model considers a few more approximations than the Carter model. For example, we are hypothesizing that $\mathrm{Fe}^{\mathrm{III}} \mathrm{dppz}$ and $\mathrm{EB}$ compete for exactly the same number of DNA-binding sites (i.e. that they show the same interaction stoichiometry). Moreover, the value of $K_{i}\{\mathrm{~EB}\}$ reported in the literature has been obtained in experimental conditions slightly different than those used in the present work. Nevertheless, the agreement between the binding constants, $K_{i}$ and $K_{\mathrm{b}}$, obtained with two different analytic techniques, provides support for the reliability of the proposed interaction models.

\section{Conclusions}

Two new $\mathrm{Fe}^{\mathrm{III}}$ complexes of the dppz ligand, i.e. $[\mathrm{Fe}(\mathrm{dppz})] \mathrm{Cl}_{3}$ and $\left[\mathrm{Fe}(\mathrm{dppz})_{2}\right] \mathrm{Cl}_{3}$, were synthesized and characterized with the aim to find DNA intercalator iron-dppz complexes with non-chelating ancillary ligands. In aqueous solution the mono-dppz cationic complex, presumably $\left[\mathrm{Fe}(\mathrm{dppz})(\mathrm{OH})_{2}\left(\mathrm{H}_{2} \mathrm{O}\right)_{2}\right]^{+}$, is the only stable species that can interact with DNA. The spectroscopic techniques used for the study of the $\mathrm{Fe}^{\mathrm{III}} \mathrm{dppz}$-DNA interaction allowed us to conclude that the metal complex binds to DNA mainly through intercalation, although other binding modes, in particular the electrostatic interaction of the complex with the DNA surface, seem to be also present and visible at $\left[\mathrm{Fe}^{\mathrm{III}} \mathrm{dppz}\right] /\left[\mathrm{DNA}_{\text {phosphate }}\right]$ molar ratios higher than 0.6.

The intrinsic binding and intercalation constants, $K_{\mathrm{b}}=(6.43 \pm$ $0.05) \times 10^{5} \mathrm{M}^{-1}$ and $K_{i}=(1.14 \pm 0.02) \times 10^{6} \mathrm{M}^{-1}$, determined by spectrophotometric and fluorescence titrations, respectively, are of the same order of magnitude of those reported for transition metal complexes of the dppz ligand, independently of the nature and charge of the metal ion and of the ancillary ligands. Moreover, the agreement between the values $K_{\mathrm{b}}$ and $K_{i}$ confirms that DNA-intercalation is the major interaction contribution compared to other possible DNA-binding modes, showing an interaction stoichiometry of approximately 2:3 metal complex-DNA base pair molar ratio.

The strength of the $\mathrm{Fe}^{\mathrm{III}} \mathrm{dppz}-\mathrm{DNA}$-binding is further confirmed by the noteworthy increase of the DNA melting temperature and by the appearance of induced $C D$ bands in the presence of increasing amounts of $\mathrm{Fe}^{\mathrm{III}} \mathrm{dppz}$ complex. Furthermore, the pronounced modifications of the intensity of selected CD bands, at [Fe $\left.{ }^{\mathrm{III}} \mathrm{dppz}\right] /$ $\left[\mathrm{DNA}_{\text {phosphate }}\right]$ molar ratios higher than 0.6 , can be ascribed to the formation of supramolecular aggregates.
In conclusion, the $\mathrm{Fe}^{\mathrm{III}} \mathrm{dppz}$ complex prepared and characterized appears to be a good candidate for the study of its potential biological activity, though this aspect is outside the aim of the present research. Indeed, the complex presents several favorable properties: its hydrolysis product strongly interacts with DNA, mainly by intercalation; iron is a biological ion and does not give rise to toxicity problems; the biological iron transport system could be used for its targeting; finally, its redox potential should fall in the biologically useful range thus enabling a potential activation by reduction mechanism.

\section{Abbreviations}

$\begin{array}{ll}\text { py } & 2,2^{\prime} \text {-bipyridine } \\ \text { CD } & \text { circular dichroism } \\ \text { CT-DNA } & \text { calf thymus DNA } \\ \text { DMSO-S } & \text { S-bonded dimethyl sulfoxide } \\ \text { Dppz } & \text { dipyrido[3,2- } a: 2^{\prime}, 3^{\prime} \text {-c]phenazine } \\ \text { EB } & \text { ethidium bromide } \\ \text { Im } & \text { imidazole } \\ \text { IP } & \text { imidazole[4,5-f][1,10]phenanthroline } \\ \text { MeIm } & 1 \text {-methylimidazol } \\ \text { Phen } & 1,10 \text {-phenantroline }\end{array}$

\section{Acknowledgement}

Financial support from Università di Palermo and MIUR within the National Research Project "Dalle singole molecole a complessi e nanostrutture: struttura, chiralità, reattività e teoria" (PRIN 2006) is gratefully acknowledged.

\section{References}

[1] T. Gupta, S. Dhar, M. Nethaji, A.R. Chakravarty, Dalton Trans. (2004) 18961900.

[2] B.M. Zeglis, V.C. Pierre, J.K. Barton, Chem. Commun. (2007) 4565-4579.

[3] K.E. Erkkila, D.T. Odom, J.K. Barton, Chem. Rev. 99 (1999) 2777-2795.

[4] K.D. Barker, B.R. Benoit, J.A. Bordelon, R.J. Davis, A.S. Delmas, O.V. Mytykh, J.T. Petty, J.F. Wheeler, N.A.P. Kane-Maguire, Inorg. Chim. Acta 322 (2001) 74-78. and references therein.

[5] C. Hiort, P. Lincoln, B. Norden, J. Am. Chem. Soc. 115 (1993) 3448-3454.

[6] L. Fin, P. Yang, J. Inorg. Biochem. 68 (1997) 79-83.

[7] Mudasir, K. Wijaya, E.T. Wahyuni, H. Inoue, N. Yoshioka, Spectrochim. Acta A 66 (2007) $163-170$

[8] Mudasir, K. Wijaya, D.H. Tjahjono, N. Yoshioka, H. Inoue, Z. Naturforsch. 59b (2004) 310-318.

[9] M. Navarro, C. Hernandez, I. Colmenares, P. Hernandez, M. Fernandez, A Sierraalta, J. Inorg. Biochem. 101 (2007) 111-116.

[10] M. Navarro, E.J. Cisneros-Fajardo, M. Fernandez-Mestre, D. Arrieche, E. Marchan, J. Biol. Inorg. Chem. 8 (2003) 401-408

[11] R.B. Nair, E.S. Teng, S.L. Kirkland, C.J. Murphy, Inorg. Chem. 37 (1998) 139-141.

[12] L.-M. Chen, J. Liu, J.-C. Chen, C.-P. Tan, S. Shi, K.-C. Zheng, L.-N. Ji, J. Inorg. Biochem. 102 (2008) 330-341.

13] V.G. Vaidyanathan, B. Unni Nair, J. Inorg. Biochem. 95 (2003) 334-342.

[14] N.J. Wheate, C.R. Brodie, J.G. Collins, S. Kemp, J.R. Aldrich-Wright, Mini Rev. Med. Chem. 7 (2007) 627-648.

[15] C.E. Keller, C. Pollard, L.K. Yeung, W. Drane Plessinger, C.J. Murphy, Inorg. Chim. Acta 298 (2000) 209-215.

[16] J.M. Rademaker-Lakhai, D. van den Bongard, D. Pluim, J.H. Beijnen, J.H.M Schellens, Clin. Cancer Res. 10 (2004) 3717-3727.

[17] A.V. Vargiu, A. Robertazzi, A. Magistrato, P. Ruggerone, P. Carloni, J. Phys. Chem. B 112 (2008) 4401-4409. and references therein.

[18] V. Brabec, O. Novàkovà, Drug Resist. Updates 9 (2006) 111-122.

[19] W. Schöniger, Mikrochim. Acta (1955) 123-129.

[20] A. Trotta, A. Barbieri Paulsen, A. Silvestri, G. Ruisi, M.A. Girasolo, R. Barbieri, J. Inorg. Biochem. 88 (2002) 14-18.

[21] A. Silvestri, G. Barone, G. Ruisi, M.T. Lo Giudice, S. Tumminello, J. Inorg. Biochem. 98 (2004) 589-594.

[22] J.F. Dickeson, L.A. Summers, Aust. J. Chem. 23 (1970) 1023-1027.

[23] P. Mc Phie, Methods Enzymol. 22 (1971) 23-32.

[24] S.D. Kennedy, R.G. Bryant, Biophys. J. 50 (1986) 669-676.

[25] A.G. Maddock, Mössbauer Spectroscopy, Horwood, Chichester, 1997.

[26] A. Stefansson, Environ. Sci. Technol. 41 (2007) 6117-6123. and references therein. 
[27] C.F. Baes Jr., R.E. Mesmer, The Hydrolysis of Cations, Krieger/Wiley, New York, 1976.

[28] F.A. Cotton, G. Wilkinson, C.A. Murillo, M. Bochmann, Advanced Inorganic Chemistry, sixth ed., Wiley, New York, 1999. p. 779.

[29] A.F.A. Peacock, A. Habtemariam, S.A. Moggach, A. Prescimone, S. Parsons, P.J. Sadler, Inorg. Chem. 46 (2007) 4049-4059.

[30] S.R. Smith, G.A. Neyhart, W.A. Kalsbeck, H. Thorp, New J. Chem. 18 (1994) 397406.

[31] M.T. Carter, M. Rodriguez, J. Bard, J. Am. Chem. Soc. 111 (1989) 8901-8911.

[32] A.M. Angeles-Boza, P.M. Bradley, P.K.-L. Fu, S.E. Wicke, J. Bacsa, K.R. Dunbar, C. Turro, Inorg. Chem. 43 (2004) 8510-8519.

[33] K. Maruyama, Y. Mishima, K. Minagawa, J. Motonaka, J. Electroanal. Chem. 510 (2001) 96-102.

[34] J.-G. Liu, B.-H. Ye, H. Li, L.-N. Ji, R.-H. Li, J.-Y. Zhou, J. Inorg. Biochem. 73 (1999) 117-122.

[35] I. Haq, P. Lincoln, D. Suh, B. Norden, B.Z. Chowdhry, J.B. Chaires, J. Am. Chem. Soc. 117 (1995) 4788-4796.
[36] R.A. Friedman, G.S. Manning, Biopolymers 23 (1984) 2671-2714.

[37] Y.-J. Liu, H. Chao, L.-F. Tau, Y.-X. Yuan, W. Wei, L.-N. Ji, J. Inorg. Biochem. 99 (2005) 530-537.

[38] M.J. Waring, J. Mol. Biol. 13 (1965) 269-274

[39] J.M. Kelly, A.B. Tossi, D.J. Mc Conell, C. Oh Uigin, Nucl. Acids Res. 13 (1985) 6017-6034.

[40] G.A. Neyhart, N. Grover, S.R. Smith, W.A. Kalsbeck, T.A. Fairly, M. Cory, H.H. Thorp, J. Am. Chem. Soc. 115 (1993) 4423-4428.

[41] M.J. Carvlin, N. Datta-Gupta, R.J. Fiel, Biochem. Biophys. Res. Commun. 108 (1982) 66-73.

[42] J.E.B. Ramos Jr., R. de Vries, J. Ruggiero Neto, J. Phys. Chem. B 109 (2005) 23661-23665.

[43] F.J. Meyer-Almes, D. Porschke, Biochemistry 32 (1993) 4246-4253.

[44] T.C. Tang, H.J. Huang, Electroanalysis 11 (1999) 1185-1190.

[45] P.K.L. Fu, P.M. Bradley, C. Turro, Inorg. Chem. 42 (2003) 878-884.

[46] N.J. Turro, Modern Molecular Photochemistry, Benjamin/Cummings, Menlo Park, CA, 1978. 